\title{
OPTIMALISASI PEMBELAJARAN STUDENT FACILITATOR AND EXPLAINING (SFE) DALAM MENINGKATKAN HASIL BELAJAR BAHASA INDONESIA KELAS XII IPS2 SMA NEGERI 1 NUSA PENIDA
}

\author{
Ni Nyoman Mulati \\ SMA Negeri 1 Nusa Penida \\ Email:mulati@gmail.com
}

\begin{abstract}
ABSTRAK
Berdarkan hasil pengamatan pada pembelajaran bahasa Indonesia pada siswa kelas XII IPS2 SMA Negeri 1 Nusa Penida mengindikasikan masalah rendahnya hasil belajar bahasa Indonesia siswa. Terlihat dari rata-rata hasil belajar yang dicapai siswa 68,97 daya serap 68,97\%, pada KKM 75 dan tingkat kentuntasan hanya mencapai $51,28 \%$. sSehingga perlu dilakukan penelitian tindakan kelas guna meningkatkan pencapian hasil belajar siswa Kelas XII IPS2 Negeri 1 Nusa Penida. Tujuan penelitian ini untuk meningkatkan hasil belajar Bahasa Indonesia siswa. Penelitian tindakan ini dilaksanakan di SMA Negeri 1 Nusa Penida. Subjek penelitian ini adalah siswa kelas XII IPS2 pada semester ganjil tahun pelajaran 2017/2018 sebanyak 39 orang. Objek penelitian adalah hasil belajar Bahasa Indonesia siswa melalui penerapan model pembelajaran kooperatif SFE. Penelitian dilaksanakan dalam dua siklus. Data diperoleh melalui tes hasil belajar dan selanjutnya dianalisis dengan menggunakan teknik deskriptif kualitatif. Hasil Penelitian menunjukan bahwa penerapan model pembelajaran kooperatif SFE dalam mata pelajaran Bahasa Indonesia dapat meningkatkan hasil belajar siswa. Hal ini dibuktikan oleh hasil belajar siswa pada siklus I mencapai rata-rata sebesar 77,77 yang berada pada kategori cukup tinggi, mengalami peningkatan pada siklus II menjadi 81,97 dengan kategori tinggi, sehingga terjadi peningkatan sebesar 4,21.
\end{abstract}

Kata kunci: Model pembelajaran kooperatif, Student Facilitator And Explaining, Hasil Belajar.

\section{ABSTRACT}

Based on the results of observations on Indonesian language learning in class XII IPS2 students of SMA Negeri 1 Nusa Penida, it indicates the problem of the low student learning outcomes of Indonesian. It can be seen from the average learning outcomes achieved by students of 68.97, 68.97\% absorption, at KKM 75 and the level of completeness only reached 51.28\%. So it is necessary to do classroom action research in order to improve the achievement of student learning outcomes of Class XII IPS2 Negeri 1 Nusa Penida. The purpose of this study is to improve student learning outcomes Indonesian. This action research was conducted at SMA Negeri 1 Nusa Penida. The subjects of this study were 39 students of class XII IPS2 in the odd semester of the 2017/2018 school year. The object of research is the students' learning outcomes of Indonesian through the implementation of the SFE cooperative learning model. The research was conducted in two cycles. The data were obtained through a test of learning outcomes and then analyzed using qualitative descriptive techniques. The results showed that the application of the SFE cooperative learning model in Indonesian subjects could improve student learning outcomes. This is evidenced by the results of student learning in the first cycle reached an average of 77.77 which is in the high enough category, an increase in the second cycle to 81.97 in the high category, resulting in an increase of 4.21 .

Keywords: Cooperative learning model, Student Facilitator and Explaining, Learning Outcomes.

\section{PENDAHULUAN}

Bahasa Indonesia merupakan alat untuk berkomunikasi secara lisan dan tulis. Oleh karena itu, mata pelajaran Bahasa Indonesia diarahkan untuk mengembangkan keterampilan-keterampilan tersebut agar lulusan mampu berkomunikasi dan berwacana dalam bahasa Indonesia pada tingkat literasi tertentu (Depdiknas, 
2006).Guru memiliki peranan yang sangat sentral dalam menentukan kuantitas dan kualitas pengajaran yang dilaksanakan. Oleh sebab itu, guru harus memikirkan dan membuat perencanaan secara seksama dalam meningkatkan kesempatan belajar bagi siswanya dan memperbaiki kualitas mengajarnya.

Namun, Hasil pengamatan pada pembelajaran Bahasa Indonesia pada siswa kelas XII IPS2 SMA Negeri 1 Nusa Penida mengindikasikan masalah-masalah sebagai berikut. a) aktivitas siswa yang teramati masih rendah, hal ini terbukti dari siswa jarang bertanya saat proses pembelajaran berlangsung dan lebih banyak didominasi oleh guru di kelas, dan b) hasil belajar Bahasa Indonesia siswa rendah, hal ini dapat dilihat dari nilai formatif pada semester 1 tahun pelajaran 2017/2018 masih rendah. Hal ini terlihat dari rata-rata hasil belajar yang dicapai siswa 68,97 daya serap $68,97 \%$, pada KKM 75 dan tingkat kentuntasan hanya mencapai 51,28\%.

Berdasarkan temuan tersebut, perlu dicarikan alternatif pemecahan masalah dengan memperbaiki proses pembelajaran, salah satunya adalah menerapkan metode pembelajaran kooperatif dalam pembelajaran Bahasa Indonesia agar dapat meningkatkan keterampilan yang pada akhirnya nanti diharapkan dapat meningkatkan kemampuan berbahasa siswa baik lisan maupu tertulis dan pemahaman konsep siswa. Menyikapi tentang beberapa alternatif tersebut maka diterapkan metode pembelajaran yang mampu mengakomodasikan seluruh alternatif tersebut dengan menerapkan model pembelajaran Student Facilitator And Explaining (SFE). Melalui penerapan Model pembelajaran SFE siswa dilatih untuk mampu mengembangkan sikap dan perilaku-perilaku sosial yang memungkinkan dirinya untuk memahami sedini mungkin realita kehidupan masyarakat yang akan dilakoninya. Untuk mengaktifkan peran siswa, seorang guru perlu memberikan pembinaan semaksimal mungkin, suatu interaksi antara siswa dan guru dalam melaksanakan proses belajar mengajar.

Permasalahan penelitian yang diajukan yaitu : "Apakah Implementasi model pembelajaran kooperatif Student Facilitator And Explaining (SFE) dapat meningkatkan hasil belajar Bahasa Indonesia siswa Kelas XII IPS2 SMA Negeri 1 Nusa Penida semester ganjil tahun pelajaran 2017/2018?". Sesuai permasalahan penelitian yang diuraikan di atas, maka tujuan penelitian tindakan ini yaitu untuk meningkatkan hasil belajar Bahasa Indonesia Kelas XII IPS2 SMA Negeri 1 Nusa Penida semester ganjil tahun pelajaran 2017/2018 dengan menerapkan model pembelajaran kooperatif $S F E$,

Hasil akhir dari kegiatan pembelajaran adalah adanya perubahan prilaku dari peserta didik. Perubahan prilaku dari aktivitas belajar disebut dengan hasil belajar. (Sudjana, 2009) mendefinisikan hasil belajar siswa pada hakikatnya adalah perubahan tingkah laku sebagai hasil belajar dalam pengertian yang lebih luas mencakup bidang kognitif, afektif, dan psikomotorik. (Dimyati, 2006) juga menyebutkan hasil belajar merupakan hasil dari suatu interaksi tindak belajar dan tindak mengajar. Berdasarkan pengertian hasil belajar di atas, disimpulkan bahwa hasil belajar adalah kemampuan-kemampuan yang dimiliki siswa setelah menerima pengalaman belajarnya. Kemampuan-kemampuan tersebut mencakup aspek kognitif, afektif, dan psikomotorik. Hasil belajar dapat dilihat melalui kegiatan evaluasi yang bertujuan 
untuk mendapatkan data pembuktian yang akan menunjukkan tingkat kemampuan siswa dalam mencapai tujuan pembelajaran.

Pembelajaran bahasa diharapkan membantu siswa mengenal dirinya, budayanya, dan budaya orang lain, mengemukakan gagasan dan perasaan, berpartisipasi dalam masyarakat yang menggunakan bahasa tersebut, dan menemukan serta menggunakan kemampuan analitis dan imaginatif yang ada dalam dirinya. Pembelajaran bahasa Indonesia diarahkan untuk meningkatkan kemampuan siswa untuk berkomunikasi dalam bahasa Indonesia dengan baik dan benar, baik secara lisan maupun tulis, serta menumbuhkan apresiasi terhadap hasil karya kesastraan manusia Indonesia (Depdiknas, 2006). Ruang lingkup mata pelajaran Bahasa Indonesia mencakup komponen kemampuan berbahasa dan kemampuan bersastra yang meliputi 4 (empat) aspek, yaitu : 1) mendengarkan, 2) berbicara, 3) membaca, dan 4) menulis.

Pembelajaran kooperatif adalah model pembelajaran yang dirancang untuk membelajarkan kecakapan akademik (academic skill), sekaligus keterampilan sosial. Slavin, Abrani, dan Chambers, 1996 (dalam Sanjaya, 2012) berpendapat bahwa, belajar melalui kooperatif dapat dijelaskan dari beberapa perspektif, yaitu perspektif motivasi, sosial, perkembangan kognitif, dan elaborasi kognitif. Perspektif motivasi artinya bahwa penghargaan yang diberikan kepada kelompok memungkinkan memungkinkan setiap anggota kelompok akan saling membantu. Dengan demikian, keberhasilan setiap individu pada dasarnya adalah keberhasilan kelompok. Perspektif sosial artinya bahwa melalui kooperatif setiap siswa akan saling membantu dalam belajar karena mereka menginginkan semua anggota kelompok memperoleh keberhasilan. Perspektif perkembangan kognitif artinya bahwa dengan adanya interaksi antar anggota kelompok dapat mengembangkan hasil siswa untuk berpikir mengolah informasi. Elaborasi kognitif artinya setiap siswa akan berusaha untuk memahami dan menimba informasi untuk menambah pengetahuan kognitifnya.

Slavin menyatakan bahwa Metode Student Facilitator and Explaining (SFE) adalah salah metode pembelajaran kooperatif yang melibatkan siswa secara aktif mmeberikan informasi mengembangkan dan menjelaskan kepada siswa lain. Menurut Slavin (dalam (Sanjaya, 2019) pada model pembelajaran ini, siswa/peserta mempresentasikan ide/pendapat pada rekan peserta lainnya. Langkah-langkah pembelajaran dengan metode Student Facilitator and Explaining ( SFE ) adalah sebagai berikut:

1. Guru menyampaikan kompetensi yang ingin dicapai

2. Guru mendemonstrasikan/menyajikan materi.

3. Memberikan kesempatan siswa/peserta untuk menjelaskan kepada peserta lainnya baik melalui bagan/peta konsep maupun yang lainnya.

4. Guru menyimpulkan ide/pendapat dari siswa

5. Guru menerangkan semua materi yang disajikan saat itu

6. Penutup.

Pembelajaran kooperatif tipe SFE memberi kesempatan kepada siswa berpartisipasi lebih aktif dalam pembelajaran dan sering mengekspresikan ide, siswa memiliki kesempatan lebih banyak dalam memanfaatkan pengetahuan dan keterampilan bahasa secara komprehensif dalam kelompoknya. Ketika siswa melakukan kegiatan-kegiatan pembelajaran untuk memecahkan 
permasalahan yang diberikan pada kelompoknya, dengan sendirinya akan mendorong potensi siswa untuk melakukan kegiatan yang mengasah kemampuan kognitif siswa ke tingkat berpikir yang lebih tinggi sehingga akan berpengaruh pada pencapaian hasil belajar siswa yang meningkat.

\section{METODE PENELITIAN}

Penelitian ini dilaksanakan di SMA Negeri 1 Nusa Penida, khususnya di Kelas XII IPS2 pada semester ganjil tahun pelajaran 2017/2018. Penelitian tindalan ini dilaksanakan pada semester ganjil tahun pelajaran 2017/2018 selama 6 bulan dari perencanaan sampai dengan pembuatan laporan. Penelitian ini dilaksanakan dari Bulan Juli sampai dengan Bulan Desember 2018. Dipilihnya Kelas XII IPS2 sebagai subyek penelitian ini karena dilihat dari perkembangan proses dan hasil belajarnya masih belum optimal dalam arti masih ada permasalahan yang dihadapi guru dalam pembelajaran Bahasa Indonesia di kelas tersebut, antara lain siswa kurang bergairah dalam belajar, kurang aktif dan hasil belajarnya masih rendah. Subjek penelitian ini adalah semua siswa Kelas XII IPS2 SMA Negeri 1 Nusa Penida yang berjumlah 39 orang yang terdiri dari 29 orang laki-laki dan 10 orang perempuan.

Yang menjadi objek penelitian ini adalah peningkatan hasil belajar belajar siswa Kelas XII IPS2 SMA Negeri 1 Nusa Penida setelah diterapkan model pembelajaran Studen Facilitator ang Explaining (SFE) dengan penilaian portofolio dalam proses pembelajaran. Penelitian yang dilakukan adalah penelitian tindakan kelas yang dirancang dalam dua siklus. Setiap siklus dalam rancangan penelitian ini terdiri dari empat tahapan, yaitu : (1) planing/perencanaan, (2) acting/tindakan,
(3) observing and evaluating/observasi dan penilaian, dan (4) reflecting/refleksi seperti Gambar 1.

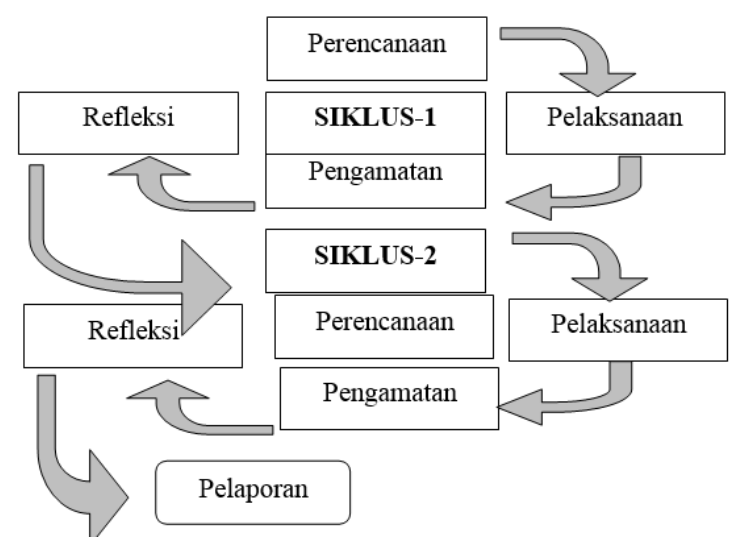

Gambar 1. Siklus Penelitian Tindakan

Kelas (Arikunto, 2010)

Teknik pengumpulan data yang digunakan dalam penelitian ini disesuaikan dengan data yang dibutuhkan. Untuk mengukur hasil belajar Bahasa Indonesia siswa digunakan instrument tes hasil belajar Bahasa Indonesia. Tes hasil belajar Bahasa Indonesia ini berupa tes tulis dan teks. Tes ini disusun oleh peneliti dengan berpedoman pada kurikulum Tingkat Satuan Pendidikan (KTSP). Tes ini digunakan untuk mengetahui untuk mengetahui hasil belajar Bahasa Indonesia.

Data hasil belajar yang mencakup aspek kognitif siswa dianalisis secara deskriptif. Pengerjaan tes akhir siklus secara individu memudahkan guru untuk mengetahui dengan baik bagaimana kemampuan kognitif per individu, sedangkan jika dikerjakan berkelompok penilaian kemampuan kognitif siswa secara individu itu sulit dibedakan. Skor kognitif individu siswa untuk setiap observasi dikonversikan ke dalam pedoman konversi nilai absolut skala 100. Data hasil belajar siswa untuk aspek kognitif ini kemudian dianalisis secara deskriptif.

Kriteria keberhasilan adalah standar yang ditetapkan oleh peneliti sebagai patokan atau tolak ukur keberhasilan. Dalam 
penelitian ini standar keberhasilan yang dijadikan patokan adalah secara klasikal siswa Kelas XII IPS2 SMA Negeri 1 Nusa Penida. Tindakan yang dianggap berhasil jika hasil belajar mencapai KKM 75 ke atas dengan kriteria hasil belajar tinggi (prosentase $80 \%$ ke atas) dengan membandingkan nilai prosentase aktivitas belajar siswa ke dalam penilaian acuan patokan (PAP) dengan skala lima.

\section{HASIL DAN PEMBEHASAN}

Pembelajaran secara langsung terbukti kurang efektif meningkatkan hasil belajar siswa. Hal ini terbukti dari analisis data yang dilakukan pada hasil belajar pra siklus menunjukan bahwa rata-rata hasil belajar Bahasa Indonesia siswa belum sesuai dengan harapan yaitu mencapai diatas KKM 75. Hal tersebut dapat dilihat dari rata-rata yang diperoleh oleh siswa mencapai 68,97 dan daya serap belajar siswa mencapai $68,97 \%$ serta ketuntasan materi mencapai 51,28\%, sehingga dipandang perlu melakukan penelitian tindakan kelas guna meningkatkan pencapian hasil belajar siswa Kelas XII IPS2 SMA Negeri 1 Nusa Penida.

\section{Hasil Belajar Tindakan Siklus I}

Kegiatan penelitian ini dilaksanakan selama 6 bulan yaitu dari bulan Juli sampai dengan Desember 2018. Tempat penelitian ini adalah di SMA Negeri 1 Nusa Penida di Kelas XII IPS2 semester 1 tahun pelajaran 2017/2018. Berdasarkan analisis data yang telah dilakukan, maka dapat disimpulkan hasil Bahasa Indonesia siswa sudah sesuai dengan harapan mencapai diatas KKM 75. Ini dapat dilihat dari hasil belajar Bahasa Indonesia siswa sudah ada peningkatan yang cukup berarti jika dibandingkan dengan tes awal (pra siklus) yang dilakukan. Hal tersebut dapat dilihat dari rata-rata yang diperoleh oleh siswa mencapai 77,77 dan daya serap belajar siswa mencapai $77,77 \%$ serta ketuntasan materi mencapai 76,92\%.

Berdasarkan data di atas, jika ratarata hasil belajar siswa dibandingkan dengan pedoman/kreteria model PAP mengacu pada Agung, maka hasil belajar yang dicapai siswa masuk pada kategori cukup tinggi. Untuk memudahkan melihat distribusi hasil belajar Bahasa Indonesia siswa Kelas XII IPS2 SMA Negeri 1 Nusa Penida pada siklus I dapat dilihat pada tabel frekuensi analisis hasil belajar Bahasa Indonesia seperti berikut ini.

Tabel 1. Analisis Hasil Belajar Bahasa Indonesia Siswa Kelas XII IPS2 di SMA Negeri 1 Nusa Penida Pada Siklus I tapel 2017/2018

\begin{tabular}{ccccc}
\hline No & $\begin{array}{c}\text { Rentang } \\
\text { nilai }\end{array}$ & Kategori & f & $\begin{array}{c}\text { Prosentase } \\
(\%)\end{array}$ \\
\hline 1 & $90 \%-$ & Sangat & 5 & $12,82 \%$ \\
& $100 \%$ & Tinggi & & \\
2 & $80 \%-$ & Tinggi & 12 & $30,77 \%$ \\
& $89 \%$ & & & \\
3 & $65 \%-$ & Cukup & 21 & $53,85 \%$ \\
& $79 \%$ & tinggi & & \\
4 & $55 \%-$ & Rendah & 1 & $2,56 \%$ \\
& $64 \%$ & & & \\
5 & $0-54 \%$ & Sangat & 0 & $0,00 \%$ \\
& & Rendah & & \\
& Total & & $\mathbf{3 9}$ & $\mathbf{1 0 0 , 0 0 \%}$ \\
\hline
\end{tabular}

Berdasarkan tabel di atas, menunjukan bahwa, $12,82 \%$ siswa mencapai hasil belajar pada kategori sangat tinggi, 30,77\% siswa mencapai hasil belajar pada kategori tinggi 53,85\% siswa mencapai hasil belajar pada kategori cukup tinggi, dan $2,56 \%$ siswa mencapai hasil belajar pada kategori rendah.

\section{Refleksi Siklus I}

Dalam penerapan model pembelajaran Studen Facilitator and Explaining (SFE), memang banyak memiliki kelebihan, namun juga memiliki kelemahan. Adapun kelemahan yang dijumpai dalam tindakan I ini yang harus 
diperbaiki pada siklus II adalah sebagai berikut. 1) Pengetahuan siswa masih cukup dangkal terhadap materi pelajaran Bahasa Indonesia, 2) Guru masih belum maksimal dalam mengarahkan jalannya kegiatan pembelajaran, sehingga masih banyak siswa kelihatannya belum berpartisifasi atau ikut bagian dalam pembelajaran, 3) Masih banyak siswa ragu-ragu dalam mengemukakan pendapatnya atau kebolehannya dalam kegiatan pembelajaran, 4) Masih banyak siswa yang memiliki kemampuan rata-rata menengah ke bawah masih malu-malu untuk bertanya pada guru atau siswa yang lebih pintar, 5) Siswa belum terbiasa belajar dalam bentuk kelompok, sehingga mereka cenderung sendiri-sendiri.

Berdasarkan analisis dan refleksi terhadap jalannya pembelajaran pada tindakan pertama ini, maka aspek-aspek yang perlu diperbaiki pada pembelajaran atau siklus berikutnya adalah sebagai berikut. 1) Memberikan pengarahan secara umum tentang langkah-langkah dalam melaksanakan pembelajaran, sehingga dapat membangkitkan partisifasi siswa secara menyeluruh dalam pembelajaran, 2) Mengarahkan siswa agar lebih banyak membaca buku-buku penunjang dan latihan soal-soal yang berkaitan dengan mata pelajaran Bahasa Indonesia, 3) Mengaktifkan seluruh siswa dalam mengemukakan pendapatnya dengan menerapkan pola tutor sebaya dalam kegiatan pembelajaran, sehingga siswa lebih lepas dalam mengemukakan pendapatnya, 4) Memberikan motivasi kepada siswa yang memiliki kemampuan rata-rata menengah ke bawah agar memiliki rasa kepercayaan diri yang tinggi, dan 5) Memberikan penghargaan bagi kelompok/siswa yang lebih berhasil sehingga menjadi lebih bersemangat.

\section{Hasil belajara Tindakan Siklus II}

Hasil analisis data menunjukkan bahwa hasil Bahasa Indonesia pada siklus II ini tergolong tinggi. Hal ini dapat dilihat dari hasil Bahasa Indonesia siswa mengalami peningkatan signifikan jika dibandingkan dengan hasil tes siklus I. Hal tersebut dapat dilihat dari rata-rata hasil Bahasa Indonesia yang diperoleh oleh siswa mencapai 81,97 dan daya serapnya mencapai $81,97 \%$ serta ketuntasan materi mencapai $87,18 \%$. Berdasarkan data di atas, jika rata-rata hasil belajar siswa dibandingkan dengan pedoman/kreteria model PAP mengacu pada Agung, maka hasil belajar yang dicapai siswa masuk pada kategori tinggi. Untuk memudahkan melihat distribusi hasil belajar Bahasa Indonesia siswa Kelas XII IPS2 SMA Negeri 1 Nusa Penida siklus II dapat peroleh nilai dari siswa pada tabel berikut.

\begin{tabular}{|c|c|c|c|c|}
\hline \multicolumn{5}{|c|}{$\begin{array}{l}\text { Tabel 2. Analisis Hasil belajar Bahasa } \\
\text { Indonesia Kelas XII IPS2 di SMA } \\
\text { Negeri } 1 \text { Nusa Penida Pada Siklus II } \\
\text { Tahun Pelajaran 2017/2018 } \\
\end{array}$} \\
\hline No & $\begin{array}{c}\text { Rentang } \\
\text { nilai }\end{array}$ & Kategori & f & $\begin{array}{c}\text { Prosentase } \\
(\%)\end{array}$ \\
\hline 1 & $\begin{array}{l}90 \%- \\
100 \%\end{array}$ & $\begin{array}{l}\text { Sangat } \\
\text { Tinggi }\end{array}$ & 12 & $30,77 \%$ \\
\hline 2 & $\begin{array}{l}80 \%- \\
89 \%\end{array}$ & Tinggi & 16 & $41,03 \%$ \\
\hline 3 & $\begin{array}{l}65 \%- \\
79 \%\end{array}$ & $\begin{array}{l}\text { Cukup } \\
\text { tinggi }\end{array}$ & 11 & $28,21 \%$ \\
\hline 4 & $\begin{array}{l}55 \%- \\
64 \%\end{array}$ & Rendah & 0 & $0,00 \%$ \\
\hline \multirow[t]{2}{*}{5} & $0-54 \%$ & $\begin{array}{l}\text { Sangat } \\
\text { Rendah }\end{array}$ & 0 & $0,00 \%$ \\
\hline & Total & & 39 & $100,00 \%$ \\
\hline
\end{tabular}

Berdasarkan pada tabel di atas, menunjukan bahwa $30,77 \%$ siswa mencapai hasil belajar kategori sangat tinggi, 41,03\% siswa mencapai hasil belajar tinggi, dan $28,21 \%$ siswa mencapai hasil belajar kategori cukup tinggi.

\section{Refleksi Siklus II}


Berdasarkan hasil tindakan pada siklus II, dilihat dari pelaksanaan pembelajaran nampaknya sudah menunjukkan lebih baik dari siklus I, hal ini disebabkan adanya perbaikan-perbaikan dari kelemahan-kelemahan yang ditemukan pada siklus II. Sikap dan ketrampilan sosial yang nampaknya dilakukan oleh siswa dalam belajar sudah tampak lebih baik dari siklus I. Dilihat dari interaksi belajar siswa dalam kelompok, nampaknya menunjukkan peningkatan yang cukup berarti, misalnya perhatian siswa dalam mengikuti pembelajaran Bahasa Indonesia sudah ada peningkatan, begitu juga keberanian siswa dalam kegiatan pembelajaran setelah penerapan pembelajaran Studen Facilitator ang Explaining (SFE) tampak semakin baik dari sebelumnya, sikap siswa dalam menghargai pendapat temannya juga mengalami peningkatan, sementara kesungguhan siswa dalam melakukan tugas yang dibebankan padanya menjadi semakin baik dari sebelumnya dan keberanian dan kemampuan siswa dalam menjawab pertanyaan yang dilontarkan oleh guru juga menunjukkan peningkatan yang cukup tinggi. Sedangkan jika dilihat dari hasil belajar siswa, nampaknya pada tindakan kedua ini lebih baik dari siklus I yang mencapai rata-rata 77,77 (siklus I) menjadi rata-rata 81,97 (siklus II). Dengan demikian target penelitian sudah tercapai, sehingga penelitian tindakan kelas ini dihentikan sampai disini.

\section{Pembahasan Hasil Penelitian}

Penerapan model pembelajaran konvensional yang diterapkan pada pra siklus berimplikasi pada rendahnya pencapian hasil belajar siswa. Berdasarkan hasil analisis data awal diketahui rata-rata hasil belajar yang dicapai siswa mencapai
68,97 dengan tingkat ketuntasan kelas mencapai $51,28 \%$, hal ini menunjukkan bahwa kemampuan siswa dalam mata pelajaran Bahasa Indonesia masih sangat rendah mengingat kriteria ketuntasan belajar siswa untuk mata pelajaran ini di SMA Negeri 1 Nusa Penida adalah 75. Dengan nilai yang cukup rendah seperti itu maka peneliti mengupayakan untuk dapat meningkatkan hasil belajar siswa menggunakan Model pembelajaran kooperatif SFE. Akhirnya dengan penerapan Model pembelajaran kooperatif SFE yang benar sesuai teori yang ada, peningkatan rata-rata hasil belajar siswa pada siklus I dapat diupayakan dan mencapai rata-rata 77,77 . Namun rata-rata tersebut belum maksimal karena hanya 30 orang siswa memperoleh nilai di atas KKM sedangkan yang lainnya belum mencapai KKM. Sedangkan prosentase ketuntasan belajar mereka baru mencapai 76,92\%. Hal tersebut terjadi akibat penggunaan Model pembelajaran kooperatif SFE belum maksimal dapat dilakukan disebabkan penerapan model tersebut baru dicobakan sehingga guru masih belum mampu melaksanakannya sesuai alur teori yang benar. Dari hasil tersebut masih ada beberapa hal yang perlu diperbaiki. Kekurangan pada kategori ini dapat diupayakan dengan cara yang betul-betul giat memperhatikan siswa yang selalu ingin main-main pada saat proses pembelajaran sedangkan dilaksanakan.

Pada siklus ke II perbaikan Hasil belajar siswa diupayakan lebih maksimal dengan peneliti membuat perencanaan yang lebih baik, menggunakan alur dan teori dari Model pembelajaran kooperatif SFE dengan benar dan lebih maksimal. Peneliti giat memotivasi siswa agar giat belajar, memberi arahan-arahan, menuntun mereka untuk mampu menguasai materi pelajaran pada 
mata pelajaran Bahasa Indonesia lebih optimal. Akhirnya dengan semua upaya tersebut peneliti mampu meningkatkan hasil belajar siswa pada siklus II menjadi rata-rata 81,97, dengan ketuntasan belajar 87,18\%. Upaya-upaya yang maksimal tersebut menuntun kepada penelitian bahwa Model pembelajaran kooperatif SFE mampu meningkatkan hasil belajar siswa. Hasil penelitian ini menunjukkan bahwa Model pembelajaran kooperatif SFE telah berhasil meningkatkan kemampuan siswa menempa ilmu sesuai harapan. Penerapan Model pembelajaran kooperatif SFE merupakan model pembelajaran yang cocok bagi siswa apabila guru menginginkan mereka memiliki kemampuan berkreasi, berargumentasi, mengeluarkan pendapat secara lugas, bertukar pikiran. Dengan demikian hipotesis yang berbunyi" Penerapan Model pembelajaran Studen Facilitator ang Explaining (SFE) dapat meningkatkan hasil belajar Bahasa Indonesia siswa Kelas XII IPS2 SMA Negeri 1 Nusa Penida dapat terjawab.

\section{PENUTUP}

\section{Simpulan}

Berdasarkan hasil pembahasan yang telah diuraikan di atas, maka dalam penelitian dapat disimpulkan bahwa, penerapan model pembelajaran Studen Facilitator and Explaining (SFE) mampu meningkatkan hasil belajar Bahasa Indonesia siswa Kelas XII IPS2 SMA Negeri 1 Nusa Penida semester ganjil tahun pelajaran 2017/2018. Hal ini dibuktikan oleh hasil belajar siswa pada siklus I mencapai rata-rata sebesar 77,77 yang berada pada kategori cukup tinggi, mengalami peningkatan pada siklus II menjadi 81,97 dengan kategori tinggi, sehingga terjadi peningkatan sebesar 4,21.

\section{Saran}

Adapun saran-saran yang dapat disampaikan sehubungan dengan hasil penelitian ini sebagai berikut: 1)Bagi pembaca agar mengembangkan penelitian ini pada subjek dan kompetensi dasar yang berbeda, 2) Bagi para guru agar keberhasilan penelitian ini dijadikan salah satu rujukan untuk meningkatkan hasil belajar siswa kelas pemula, 3) Bagi sekolah agar memfasilitasi kegiatan inovasi guru dalam pembelajaran melalui kegiatan penelitian tindakan kelas.

\section{DAFTAR PUSTAKA}

Arikunto. (2010). Suharsimi Arikunto.pdf. In Prosedur Penelitian Suatu Pendekatan Praktik-Revisi ke X.

Depdiknas. (2006). Panduan Penyusunan Kurikulum Tingkat Satuan Pendidikan. Jakarta: BNSP Depdiknas.

Dimyati, M. (2006). Belajar dan pembelajaran. Jakarta: Rineka Cipta.

Sanjaya, W. (2019). Strategi pembelajaran berorientasi standar proses pendidikan.

Sudjana, N. (2009). Penilaian Hasil Proses Belajar Mengajar. Sinarbaru. 